\title{
ANALISIS APLIKASI E-REKON-LK TERHADAP REKONSILIASI LAPORAN KEUANGAN PADA KANTOR WILAYAH DIREKTORAT JENDERAL PERBENDAHARAAN NEGARA PROVINSI UTARA
}

\author{
Jean Gabril Oflagi ${ }^{1}$, Hendrik Manossoh ${ }^{2}$, Stanley Kho Walandouw ${ }^{3}$ \\ 1,2,3 Jurusan Akuntansi, Fakultas Ekonomi dan Bisnis, Universitas Sam Ratulangi, Jl. Kampus Bahu, Manado, \\ 95115, Indonesia \\ E-mail : jeanoflagi@icloud.com
}

\begin{abstract}
In order to realize an effective, efficient, accurate, accountable, and transparent Central Government Financial Report, Online Reconciliation System is required to ease the Local Government, The State Ministry/Institute and Regional Office of General Directorate of Budget Financing. This study aims to investigate the process of reconciliation using the electronic reconciliation aplications (e-Rekon-LK). Research method used in this study is descriptive analysis method. This research stated that electronic reconciliation based on website application makes the reconciliation process easier where the financial statement only exist at the lowest level between Local Government and Treasury Office that conducts to all the financial data transactions to fulfill the effectiveness and efficiency, also the accountability and transparency in financial statement. However, it has some obstacles where people doesn't really understand and being precise in doing it and also because of the internet in some places is not working properly.
\end{abstract}

Keywords : Reconciliation, e-Rekon-LK

\section{PENDAHULUAN}

Pemerintah pusat mempunyai 24 ribu (pada tahun anggaran 2016 menerbitkan DIPA sebanyak 23.610 satker dan 3900-an satker yang masih mempunyai saldo neraca walaupun tidak menerima DIPA) lebih satuan kerja. Hal ini membutuhkan sistem akuntansi yang memadai untuk menyusun laporan keuangannya. Salah satu perangkat yang mendukung pelaksanaan sistem akuntansi adalah perangkat lunak komputer atau aplikasi komputer. Aplikasi yang digunakan saat ini adalah Sistem Akuntansi Instansi Berbasis Akrual (SAIBA). Unit Akuntansi mulai dari satuan kerja sampai dengan Kementerian Negara/Lembaga menggunakan aplikasi SAIBA. Sehingga ada aplikasi SAIBA tingkat satuan kerja sampai dengan tingkat Kementerian Negara/Lembaga. Data SAIBA satuan kerja setiap bulan direkonsiliasi dengan Kantor Pelayanan Perbendaharaan Negara (KPPN) untuk validasi data. Rekonsiliasi ini juga dilakukan pada tingkat wilayah sampai dengan Kementerian Negara/Lembaga. Aplikasi SAIBA telah berhasil mengantarkan sebagian besar laporan keuangan Kementerian Negara/Lembaga mendapat opini Wajar Tanpa Pengecualian (WTP) dan Laporan Keuangan Pemerintah Pusat (LKPP) mendapat opini Wajar Dengan Pengecualian pada tahun 2015.Disamping keberhasilannya, SAIBA menyisakan sedikit masalah dalam implementasinya.

Pada tahun 2016, pemerintah merilis aplikasi berbasis webe-Rekon-LK yang didesain memberi solusi atas masalah yang masih tersisa dalam Aplikasi Sistem Akuntansi Instansi Berbasis Akrual (SAIBA). Aplikasi $e$-Rekon-LK dirancangkarena adanya temuan kinerja oleh Badan Pemeriksa Keuangan (BPK) atas pengendalian internal. Badan Pemeriksa Keuangan (BPK) terkait kelemahan pengendalian aplikasi, data yang dihasilkan sistem sebelumnya dinilai kurang efisien dan efektif dalam hal pelaksanaan rekonsiliasi dan pelaksanaan proses konsolidasi laporan keuangan. 
Aplikasi e-Rekon-LK digunakan untuk mengkonsolidasi data seluruh Satuan Kerja dan untuk rekonsiliasi antara Satuan Kerja dengan data Kantor Pelayanan Perbendaharaan Negara (KPPN). Aplikasi berbasis web e-Rekon-LK mempermudah proses rekonsiliasi dimana rekonsiliasi laporan keuangan hanya ada pada satu level, yaitu level terendah antara Satuan Kerja dengan Kantor Pelayanan Perbendaharaan Negara (KPPN) yang dilakukan terhadap seluruh data transaksi keuangan untuk memenuhi prinsip-prinsip efektivitas dan efisiensi, serta akuntabilitas dan transparansi dalam pelaporan keuangan, tanpa mengurangi keandalan laporan keuangan itu sendiri. Data valid hasil rekonsiliasi digunakan untuk penyusunan laporan keuangan tingkat wilayah sampai dengan tingkat Kementerian/Lembaga. Penggunaan data dengan single database pada e-Rekon-LK menyebabkan tidak diperlukan lagi rekonsiliasi tingkat wilayah sampai dengan tingkat Kementerian/Lembaga, walaupun demikian dalam pelaksanaannya masih ditemukan adanya perbedaan data antara Sistem Akuntansi Instansi (SAI) dan Sistem Akuntansi Pusat (SiAP). Sistem Akuntansi Instansi (SAI) dan Sistem Akuntansi Pusat (SiAP) memiliki pusat data yang berbeda meskipun dokumen sumber yang menyusun data tersebut sama. Sehingga jika data tersebut digunakan untuk menyusun laporan keuangan, maka laporan yang dihasilkan menjadi tidak valid dan akuntabel.

\section{TINJAUAN PUSTAKA}

\subsection{Akuntansi Sektor Publik}

Akuntansi sektor publik adalah proses pencatatan, pengklasifikasian, pelaporan data keuangan dari suatu kegiatan ekonomi sebagai bentuk pertanggung jawaban atas pengelolaan sumber daya dan memberikan informasi keuangan kepada pihak-pihak tertentu dalam rangka pengambilan keputusan. tujuan akuntansi sektor publik menurut American Accounting Association (AAA) (dalam Sujarweni, 2015 : 2) yaitu untuk memberikan informasi yang diperlukan untuk mengelola secara tepat, efisien, dan ekonomis atas alokasi suatu sumber daya yang dipercayakan kepada organisasi dan memberikan informasi yang memungkinkan bagi manajer untuk melaporkan pelaksanaan tanggungjawab secara tepat dan efektif program dan penggunaan sumber daya yang menjadi wewenangnya.

\subsection{Standar Akuntansi Pemerintahan}

Standar Akuntansi Pemerintahan (SAP) merupakan standar yang dibuat dalam rangka: transparansi, akuntabilitas penyelenggaraan akuntansi pemerintahan, dan untuk meningkatkan kualitas Laporan Keuangan Pemerintah Pusat (LKPP) dan Laporan Keuangan Pemerintah Daerah (LKPD). Standar Akuntansi Pemerintah (SAP) dibuat berdasarkan prinsip-prinsip untuk menyusun laporan keuangan pemerintah.

\subsection{Standar Akuntansi Pemerintahan yang berlaku di Indonesia}

Peraturan Pemerintah Nomor 71 Tahun 2010 menerangkang bahwa dalam Standar Akuntansi Pemerintahan terdapat dua basis yaitu Standar Akuntansi Berbasis Akrual dan Standar Akuntansi Pemerintahan Kas Menuju Akrual. Standar Akuntansi Berbasis Akrual di pelaporan finansial mengakui pendapatan, beban, aset, utang, dan ekuitas, sertadalam pelaporan pelaksanaan anggaran berdasarkan basis yang ditetapkan dalam Anggaran Pendapatan dan Belanja Negara (APBN) dan Anggaran Pendapatan dan Belanja Daerah (APBD mengakui pendapatan, belanja, dan pembiayaan. Sedangkan, Standar Akuntansi Pemerintah Berbasis Kas Menuju Akrual yaitu Standar Akuntansi Pemerintah (SAP) yang mengakui pendapatan, belanja, dan pembiayaan berbasis kas, serta mengakui aset, utang, dan ekuitas dana berbasis akrual.

\subsection{Sistem Akuntansi Pemerintah Pusat}

Berdasarkan Peraturan Menteri Keuangan No.213/PMK.O5/2013 dijelaskan Sistem Akuntansi Pemerintah Pusat (SAPP) merupakan rangkaian sistematik dari prosedur, penyelenggara, peralatan, dan elemen lain untuk mewujudkan fungsi akuntansi sejak 
pengumpulan data, pencatatan, pengikhtisaran sampai dengan pelaporan posisi keuangan dan operasi keuangan pada Pemerintah Pusat. Dalam Sistem Akuntansi Pemerintah Pusat terdiri atas dua bagian yaitu Sistem Akuntansi Pusat (SiAP) dan Sistem Akuntansi Instansi (SAI).

1. Sistem Akuntansi Pusat (SiAP)

Sistem Akuntansi Pusat yaitu serangkaian prosedur manual maupun yang terkomputerisasi mulai dari pengumpulan data, pencatatan, pengikhtisaran, sampai dengan pelaporan posisi keuangan, dan operasi keuangan pada Kementerian Keuangan selaku Bendahara Umum Negara

2. $\quad$ Sistem Akuntansi Instansi (SAI)

Sistem Akuntansi Instansi (SAI) yaitu serangkaian prosedur manual maupun yang terkomputerisasi mulai dari pengumpulan data, pencatatan, pengikhtisaran sampai dengan pelaporan posisi keuangan dan operasi keuangan pada Kementerian Negara/Lembaga.

\subsection{Laporan Keuangan Pemerintah}

Laporan keuangan disusun untuk menyediakan informasi mengenai posisi keuangan dan seluruh transaksi yang dilakukan oleh suatu entitas pelaporan selama satu periode pelaporan. Agar supaya laporan keuangan pemerintah memenuhi kualitas yang diinginkan informasi yang termuat dalam laporan keuangan harus memenuhi prasyarat normative yaitu relevan, andal, dapat dibandingkan dan dapat dipahami.

\subsection{Laporan Keuangan Pemerintah Pusat}

Salah satu perwujudan nyata dari penerapan transparansi dan akuntabilitas adalah melalui penyusunan laporan pemerintahan yang relevan dan andal, yang disusun berdasarkan Standar Akuntansi Pemerintahan (SAP) dan sistem akuntansi yang menyediakan prosedur pemrosesan transaksi sampai menjadi laporan keuangan.

Laporan keuangan pemerintah terdiri dari laporan pelaksanaan anggaran (budgetary reports), laporan finansial, dan Catatan atas Laporan Keuangan (CaLK). Laporan pelaksanaan anggaran terdiri dari :

1. Laporan Realisasi Anggaran (LRA)

2. Laporan Perubahan Saldo Anggaran Lebih (SAL).

Sedangkan, laporan finansial terdiri dari :

1. Neraca

2. Laporan Operasional (LO)

3. Laporan Perubahan Ekuitas (LPE)

4. Laporan Arus Kas (LAK)

\subsection{Rekonsiliasi}

Rekonsiliasi merupakan proses pencocokan data transaksi keuangan Kantor Pelayanan Perbendaharaan Negara dan Satuan Kerja berdasarkan dokumen sumber yang sama. Rekonsiliasi eksternal Kantor Pelayanan Perbendaharaan Negara merupakan pencocokan data antara Kantor Pelayanan Perbendaharaan Negara (KPPN) selaku Unit Akuntansi Kuasa Bendahara Umum Negara-Daerah (UAKBUN-D) dengan satuan kerja selaku Unit Akuntansi Kuasa Pengguna Anggaran (UAKPA).

\subsection{Aplikasi Elektronik Rekonsiliasi Laporan Keuangan ( $e$-Rekon-LK)}

Menurut Peraturan Menteri Keuangan Nomor 05 Tahun 2016 tentang Perubahan Atas Peraturan Menteri Keuangan, $e$-Rekon-LK adalah aplikasi berbasis web yang dikembangkan dalam rangka proses rekonsiliasi data transaksi keuangan dan penyusunan Laporan Keuangan Kementerian Negara/Lembaga tahun 2016. Dengan adanya aplikasi ini, diharapkan:

1. Proses rekonsiliasi menjadi lebih mudah karena dapat dilakukan oleh satker secara mandiri dari lokasi mana saja, tidak perlu datang ke Kantor Pelayanan Perbendaharaan Negara. 
2. Terbentuk single database yang berisi data seluruh satker di seluruh kementerian lembaga sehingga sangat membantu kementerian dan lembaga dalam menyusun/mengkompilasi laporan keuangan.

3. Data yang dikirim oleh Unit Akuntansi Kuasa Pengguna Anggaran (UAKPA) ke Kantor Pelayanan Perbendaharaan Negara (KPPN) sama dengan data yang dikonsolidasi oleh Unit Akuntansi Pembantu Pengguna Anggaran Wilayah (UAPPA-W), Unit Akuntansi Pembantu Pengguna Anggaran Eselon 1 (UAPPA-E1), dan Unit Akuntansi Pembantu Pengguna Anggaran (UAPPA) untuk menyusun laporan keuangan.

4. Menciptakan keseragaman laporan di tiap level unit akuntansi dan mempercepat penyusunan Laporan Keuangan Kementerian/Lembaga. Dengan adanya e-Rekon-LK tentunya mengakibatkan tidak diperlukannya lagi rekonsiliasi tingkat atas dan Aplikasi Sistem Akuntansi Instansi Basis Akrual (SAIBA) tingkat atas, SAIBA adalah aplikasi yang digunakan satuan kerja.

\subsection{Pengendalian Internal COSO}

Pada edisi yang baru, COSO (2013) mendefinisikan pengendalian internal yaitu "Internal control is a process, affected by an entity's board of directors, management, and other personnel, designed to provide reasonable assurance regarding the achievement of objectives relating to operations, reporting, and compliance". Pengertian pengendalian internal control menurut COSO tersebut, dapat dipahami bahwa pengendalian internal adalah proses, karena hal tersebut menembus kegiatan operasional organisasi dan merupakan bagian integral dari kegiatan manajemen dasar. Komponen-komponen dalam pengendalian internal yaitu:

1. Lingkungan Pengendalian(Control Invironment)

2. Penilaian Risiko (Risk Assessment)

3. Aktivitas Pengendalian (Control Activities)

4. Informasi Dan Komunikasi (Information And Communication)

5. Aktivitas Pemantauan(Monitoring Activities)

\subsection{Penelitian Terdahulu}

Penelitian terdahulu yang dijadikan acuan penulis untuk melakukan penelitian tentang proses rekonsiliasi menggunakan aplikasi berbasis web e-Rekon-LK yang dirilis tahun 2016 yaitu penelitian yang dilakukan oleh Saifhul Syahdan tahun 2012 yang meneliti tentang proses rekonsiliasi di Kantor Pelayanan Perbendaharaan Negara yang menyatakan bahwa proses rekonsiliasi manual masih menyisakan beberapa masalah meskipun sudah berjalan dengan baik.

\section{METODE PENELITIAN}

\subsection{Jenis Penelitian}

Penelitian ini menggunakan penelitian deskriptif kualitatif. Peneliti menggunakan penelitian deskriptif kualitatif karena peneliti ingin menganalisis proses rekonsiliasi menggunakan aplikasi e-Rekon-LK dan membandingkan proses rekonsiliasi yang lama dengan proses rekonsiliasi yang baru dan akan dibandingkan dengan Standar Operasional Prosedur (SOP) dan pengendalian internal COSO.

\subsection{Tempat dan Waktu Penelitian}

Penelitian ini dilakukan pada Kantor Wilayah Direktorat Jenderal Perbendaharaan Negara Provinsi Sulawesi Utara di Lantai III Gedung KeuanganNegara pada Jalan Bethesda nomor 8 Manado, Sulawesi Utara. Penelitian ini dilakukan dalam jangka waktu satu bulan, yaitu bulan Maret-April 2018.

\subsection{Metode Analisis}

Metode analisis yang digunakan dalam penelitian ini adalah metode analisis deskriptif yaitu peneliti mengumpulkan data berupa Standar Operasional Prosedur, proses rekonsiliasi 
yang dulu dan proses rekonsiliasi menggunakan aplikasi $e$-Rekon-LK, kelebihan dan tantangan aplikasi $e$-Rekon-LK serta cara menganalisa data hasil rekonsiliasi pada Kantor Wilayah Direktorat Jenderal Perbendaharaan Negara. Kemudian, peneliti mencoba membandingkan prosedur atau cara kerja sistem rekonsiliasi yang lama dan sistem rekonsiliasi yang baru dan akan dibandingkan dengan Standart Operasional Prosedur yang dijadikan sebagai bahan acuan. Selanjutnya, peneliti mencoba menganalisa proses rekonsiliasi dengan menggunakan alat analisis COSO lalu ditarik kesimpulan.

\section{HASIL ANALISIS DAN PEMBAHASAN}

\subsection{Hasil Analisis}

\subsubsection{Prosedur Rekonsiliasi}

Berdasarkan surat Direktur Jendral Perbendaharaan Nomor : S-4841/PB/2016 tanggal 14 Juni 2016 hal Pelaksanaan Rekonsiliasi Eksternal Tingkat KPPN, proses rekonsiliasi dilaksanakan secara mandiri dan online dengan menggunakan Aplikasi e-Rekon-LK yang berbasis web dan dapat diakses melalui internet pada alamat website: www.erekonlk.djpbn.kemenkeu.go.id.

Prosedur dalam pelaksanaan rekonsiliasi secara online yaitu :

1. Satker menghubungi KPPN (Front Office Seksi Verifikasi dan Akuntansi) untuk mendapatkan username dan password Aplikasi e-Rekon-LK.

2. Satker segera melengkapi identitas user operator pada Alikasi e-Rekon-LK meliputi Nama, NIP, Jabatan, Alamat, Telepon, dan e-mail. Password dapat dirubah oleh user sesuai yang dikehendaki. Apabila user lupa dengan password, maka dapat meminta KPPN untuk melakukan reset password.

3. Satker mengirim email ke KPPN yang berisi register pengiriman, sedangkan ADK diunggah dari aplikasi SAIBA versi terbaru ke Aplikasi e-Rekon-LK melalui menu upload rekonsiliasi (contoh SPAN_KD015085287850716K.zip).

4. Setelah satker upload Arsip Data Komputer (ADK), KPPN menerima register pengiriman dan mengunduh Arsip Data Komputer (ADK) yang dikirim satker yang kemudian diproses oleh sistem secara periodik.

5. Kemudian tunggu hingga kolom status menampilkan status "Menunggu Persetujuan Berita Acara Rekonsiliasi (BAR)". Jika status masih "Upload" atau "Proses Rekon (SAI Bawah)" berarti proses rekonsiliasi masiih berlangsung pada sistem.

6. Setelah status rekon berubah menjadi "Menunggu Persetujuan Berita Acara Rekonsiliasi (BAR)" operator satker dan KPPN men-download file Laporan Hasil Rekonsiliasi (LHR) berformat excel dengan meng-klik tombol menu warna hijau (contoh file : 160500_528785_excel.xls).

7. Buka file dan analisa hasil rekon tersebut. Kemudian cocokan hasil rekon antara satuan kerja dengan KPPN yaitu pagu, realisasi belanja, realisasi pengembalian belanja, estimasi pendapatan, realisasi Pendapatan Negara Bukan Pajak (PNBP), pengembalian pendapatan (meliputi pengembalian PNBP dan Pengembalian Pajak), mutasi uang persediaan/tambahan uang persediaan, kas di bendahara pengeluaran, kas pada Badan Layanan Umum (BLU) dana lainnya di Kementerian/Lembaga dari hibah, dengan cara:

a. Rekonsiliasi Pagu Belanja

Bandingkan elemen data pagu belanja antara Kantor Pelayanan Perbendaharaan Negara (KPPN) dengan Unit Akuntansi Kuasa Pengguna Anggaran (UAKPA).

b. Rekonsiliasi Estimasi Pendapatan 
Bandingkan elemen data Estimasi Pendapatan yang dialokasikan antara KPPN dengan Unit Akuntansi Kuasa Pengguna Anggaran (UAKPA) dan Unit Akuntansi Kuasa Pengguna Anggaran Bendahara Umum Negara (UAKPA BUN).

c. Rekonsiliasi Pendapatan

Bandingkan elemen data realisasi pendapatan dengan Unit Akuntansi Kuasa Pengguna Anggaran (UAKPA) dan Unit Akuntansi Kuasa Pengguna Anggaran Bendahara Umum Negara (UAKPA BUN).

1. Pendapatan Pajak

Rekonsiliasi terhadap realisasi penerimaan pajak mengikuti ketentuan peraturan yang berlaku.

2. Pendapatan Negara Bukan Pajak (PNBP)

Rekonsiliasi terhadap realisasi penerimaan Negara bukan pajak dilakukan dengan ketentuan, apabila penyetor melakukan penyetoran pada bank yang bukan merupakan bank persepsi mitra kerja Kantor Pelayanan Perbendaharaan Negara (KPPN) bersangkutan, satker harus dapat membuktikannya dengan melampirkan bukti penerimaan Negara Surat Setoran Bukan Pajak (SSBP) dan Surat Setoran Pajak Bumi dan Bangunan (SSPB) yang disertai Nomor Transaksi Penerimaan Negara (NTPN)/ Nomor Transaksi Bank (NTB). Atas transaksi di atas harus dijelaskan di dalam Berita Acara Rekonsiliasi.

3. Hibah

UAKBUN-Daerah dengan UAKPA dan UAKPA BUN melakukan rekonsiliasi pendapatan hibah dalam bentuk barang, jasa, dan surat berharga menggunakan data yang terdiri dari Memo Pencatatan Hibah Langsung Bentuk Barang Jasa/Surat Berharga (MPHL BJS) dan persetujuan MPHL BJS.

Bandingkan kode BA, kode unit eselon 1, akun, kode satker, dan jumlah rupiah.

d. Rekonsiliasi Pengembalian Pendapatan

Bandingkan elemen data Pengembalian Pendapatan berupa kode BA, Es 1, kode satker, kode KPPN, akun dan jumlah rupiah BUN antara KPPN dengan UAKPA dan UAKPA BUN.

e. Rekonsiliasi Realisasi Belanja

Rekonsiliasi belanja berlaku untuk satker yang pengeluarannya bersumber dari rupiah murni, PNBP, dan hibah langsung dalam negeri/rupiah.

1. Bandingkan kode bagian anggaran, Es 1, kode satker, kode KPPN, program, kegiatan, output, akun, dan jumlah rupiah KPPN dengan data UAKPA dan UAKPA BUN.

2. Bandingkan jumlah rupiah ringkasan belanja antara data Kantor Pelayanan Perbendaharaan Negara dengan data Unit Akuntansi Kuasa Pengguna Anggaran dan Unit Akuntansi Kuasa Pengguna Anggaran Bendahara Umum Negara.

f. Rekonsiliasi Realisasi Pengembalian Belanja

Rekonsiliasi pengembalian belanja ini berlaku untuk satker yang pengeluarannya bersumber dari rupiah murni, PNBP, dan hibah langsung dalam negeri/rupiah. Bandingkan kode anggaran, BA, Es 1, kode satker, kode Kantor Pelayanan Perbendaharaan Negara, program, kegiatan, output, akun, jumlah rupiah, antara data di Kantor Pelayanan Perbendaharaan Negara dengan data Unit Akuntansi Kuasa Pengguna Anggaran Bendahara Umum Negara.

1. Mutasi Uang Persediaan

Bandingkan kode bagian anggaran, Es 1, kode satker, kode KPPN, akun, dan jumlah rupiah KPPN dengan data UAKPA dan UAKPA BUN. 


\section{Neraca}

Neraca berlaku untuk kas di bendahara pengeluaran, kas lainnya di

Kementerian Negara/Lembaga dari hibah, dan kas pada badan layanan umum.

1. Kas di Bendahara Pengeluaran

Bandingkan kas di bendahara pengeluaran yang terdapat dalam neraca SAI/SABUN dengan neraca SAU.

2. Kas Lainnya di Kementerian Negara/Lembaga dari Hibah

Bandingkan kas lainnya dan setara kas yang berasal dari hibah langsung yang terdapat dalam neraca SAI/SA-BUN dengan neraca SAU.

3. Kas pada Badan Layanan Umum

Bandingkan kas pada Badan Layanan Umum yang terdapat dalam neraca SAI dengan neraca SAU.

8. KPA dapat melihat hasil rekon (dengan download file Laporan Hasil Rekonsiliasi) sebelum menandatangani BAR. Pastikan data KPA sudah diisi sebelum melakukan penandatanganan agar nama KPA, NIP, dan Jabatan di BAR tidak kosong.

9. Status rekonsiliasi akan berubah menjadi "Menunggu TTD Kasi Vera" dan akan ditandatangani juga secara elektronis oleh Kasi Vera KPPN.

10. BAR yang sudah ditandatangani Kasi Vera KPPN maka akan memunculkan status "BAR Siap Download" yang berarti proses rekonsiliasi di Aplikasi eRekon-LK sudah selesai.

Operator satker mendownload BAR beserta rincian hasil rekon dengan menekan tombol menu bergambar printer, download di menu "Download zip" dan "Cetak Bar".

\subsubsection{Manfaat e-Rekon-LK}

Beberapa permasalahan yang muncul dalam konsolidasi laporan keuangan adalah (1) proses rekonsiliasi antara Satker dengan KPPN harus dilakukan dengan tatap muka (2) integritas data karena ada perbedaan sebagian data antara SAIBA satker sampai dengan Kemterian/Lembaga, (3) proses konsolidasi yang memakan waktu dan biaya, dan (4) monitoring dan pelaksanaan rekonsialisi dan perekaman data akuntansi yang kurang maksimal. E-Rekon-LK yang berbasis web dapat menyelesaikan permasalahan pertama, karena satker dapat mengerjakan rekonsiliasi dari kantor masing-masing, tidak perlu datang ke KPPN. Hal ini juga mengurangi biaya perjalanan ke KPPN untuk melakukan rekonsiliasi.

Permasalahan kedua yaitu integritas data karena ada perbedaan sebagian data antara SAIBA satker s. K/L dapat diselesaikan/dikurangi dengan aplikasi e-Rekon-LK. Data SAIBA satker diunggah di aplikasi e-Rekon-LK untuk dilakukan rekonsiliasi dengan data KPPN yang berasal dari Sistem Pemerintahan dan Anggaran Negara. Setelah disetujui KPPN maka data satker disimpan di aplikasi e-Rekon-LK. Data satker diolah menjadi laporan keuangan tingkat satker, wilayah, eselon 1 dan K/L pada malam hari. Keesokan harinya UAPPAW, UAPPAE-1 dan UAPA sudah dapat mencetak laporan keuangannya. Karena tidak ada lagi pengiriman dari satker ke wilayah, dari wilayah ke eselon 1, dan dari eselon 1 ke Kementerian/Lembaga, maka permasalahan perbedaan data antar unit akuntansi di SAI tidak ada lagi.

Proses tersebut sekaligus menyelesaikan permasalahan ketiga yaitu mempercepat proses konsolidasi laporan keuangan pada tingkat wilayah, eselon 1, dan Kementerian/Lembaga. Konsolidasi menjadi lebih cepat karena tidak perlu lagi proses kirim data ke unit akuntansi di atasnya, kemudian proses terima di unit akuntansi terkait, tidak perlu lagi memvalidasi data kiriman satker karena sudah direkonsiliasi dengan Kantor Pelayanan Perbendaharaan Negara (KPPN), dan tidak ada lagi aktivitas perbaikan data berupa pengulangan proses kirim dan terima data.

Permasalahan keempat yaitu monitoring, dapat dilakukan dengan lebih cepat. Karena aplikasi e-Rekon-LK memberikan informasi awal atas perekaman yang tidak normal. Atas 
transaksi tidak normal dilakukan penelaahan dan koreksi bila diperlukan. Sisa sebagian langkah telaah yang informasinya tidak disediakan aplikasi e-Rekon-LK dapat dilakukan oleh petugas terkait. Monitoring data satker dapat dilakukan setiap hari.

Sumbangan e-Rekon-LK dalam pencapaian Wajar Tanpa Pengecualian (WTP). Penyatuan data pada $e$-Rekon-LK menyebabkan kualitas dan integritas data menjadi lebih baik. Tidak terjadi lagi data hardcopybeda dengan softcopy karena semua laporan dicetak dari satu data yang sama. Misalnya laporan entitas tingkat wilayah dan eselon 1 yang sebelumnya masih memungkinkan berbeda dengan data yang dikonsolidasi oleh KL karena database yang terpisah-pisah. Selain itu, konsistensi dan kesinambungan data akan lebih terjamin dengan adanya penyatuan database.

Manfaat lain yang ingin dihadirkan oleh e-Rekon-LK adalah kemudahan dalam melakukan monitoring, baik monitoringLaporan Keuangan maupun monitoring atas pelaksanaan dan hasil rekonsiliasi. e-Rekon-LK memudahkan untuk mendapatkan informasi mengenai data yang tidak normal untuk ditindaklanjut secara khusus. e-Rekon-LK juga memudahkan pengawasan dalam proses rekonsiliasi.

\subsubsection{Hambatan Aplikasi e-Rekon-LK}

Berdasarkan hasil wawancara yang dilakukan penulis dengan Bapak Heri Jasmadi selaku Pelaksana pada Seksi Pembinaan Sistem Akuntansi Pemerintah Pusat Kanwil Ditjend Perbendaharaan Negara Provinsi Sulawesi Utara, ternyata dalam implementasinya aplikasi eRekon-LK masih ditemukan hambatan yang lebih tepat jika disebut sebagai tantangan, yaitu:

1. Adanya pergantian operator pada satuan Kerja akantetapi operator Satuan Kerja yang lama tidak mengajarkan mengenai program dan cara kerja (sharing knowledge) kepada operator yang baru hal tersebut berpengaruh terhadap pemahaman aplikasi $e$ Rekon-LK.

2. Belum adanya jaringan internet di daerah-daerah tertentu misalnya didaerah kepulauan hal tersebut berpengaruh pada saat mengupload data dari daerah tersebut hal tersebut mengakibatkan operator Satuan Kerja harus datang langsung ke KPPN atau mencari tempat yang ada jangkauan internetnya untuk mengupload data menggunakan username sendiri.

Data yang masuk kedalam single database Sistem Perbendaharaan dan Anggaran Negara (SPAN) bisa diakses seluruh user, data harus diyakinkan pada level ini bahwa data Sistem Akuntansi Instansi (SAI) dan Sistem Akuntansi Pemerintah (SiAP) sama, valid, dan akurat. Namun berdasarkan informasi yang didapatkan penulis karena berbagai keterbatasan seperti kurangnya Sumber Daya Manusia Satuan Kerja yang bisa menjalankan komputer sekaligus internet, operator kurang teliti dalam penginputan data dan pihak Satuan Kerja yang tidak langsung memberitahukan ketika terjadi ralat Surat Perintah Membayar menyebabkan data SAI dan data SiAP tidak sama.

\subsubsection{Data Hasil Rekonsiliasi}

Analisa dari Hasil Rekonsiliasi yang berpedoman pada Peraturan Menteri Keuangan Republik Indonesia Nomor 104/PMK.05/2017 tentang Pedoman Rekonsiliasi Dalam Penyusunan Laporan Keuangan Lingkup Bendahara Umum Negara Dan Kementerian Negara/Lembaga yang dilaksanakan Sistem Akuntansi Pusat dan Sistem Akuntansi Instansi yang ada di Gedung Keuangan Negara Manado (Kode Satuan Kerja 450913) sampai dengan bulan Nopember tahun anggaran 2017.

1. Pagu Anggaran, Rupiah SiAP dan SAI adalah 6.207.347.000 status hasil rekonsiliasi seluruhnya SAMA.

2. Estimasi Pendapatan, Rupiah SiAP dan SAI adalah 0 status hasil rekonsiliasi seluruhnya SAMA. 
3. Laporan Realisasi Belanja, Rupiah SiAP dan SAI adalah 4.772.112.399 status hasil rekonsiliasi seluruhnya SAMA.

4. Pengembalian Belanja, Rupiah SiAP dan SAI adalah -3.310.000 status hasil rekonsiliasi seluruhnya SAMA.

5. Realisasi Pendapatan Bukan Pajak, Rupiah SiAP dan SAI adalah 5.453.800 status hasil rekonsiliasi seluruhnya SAMA.

6. Pengembalian Pendapatan Bukan Pajak, Rupiah SiAP dan SAI adalah 0 status hasil rekonsiliasi seluruhnya SAMA.

7. Pengembalian Pajak, Rupiah SiAP dan SAI adalah 0 status hasil rekonsiliasi seluruhnya SAMA.

8. Mutasi uang persediaan, Rupiah SiAP dan SAI adalah 75.000.000 status hasil rekonsiliasi seluruhnya SAMA.

9. Kas di Bendahara Pengeluaran, Rupiah SiAP dan SAI adalah 75.000.000 status hasil rekonsiliasi seluruhnya SAMA.

10. Saldo Kas Lainnya dari Hibah Langsung, Rupiah SiAP dan SAI adalah 0 status hasil rekonsiliasi seluruhnya SAMA.

11. Saldo Kas Badan Layanan Umum, Rupiah SiAP dan SAI adalah 0 status hasil rekonsiliasi seluruhnya SAMA.

\subsection{Pembahasan}

Laporan Keuangan Pemerintah Pusat (LKPP) adalah sebuah laporan yang merupakan pertanggungjawaban dari para para pengelola kegiatan yang disebut satuan kerja yang dananya berasal dari Anggaran Pendapatan dan Belanja Negara (APBN). Rekonsiliasi dilaksanakan untuk mengidentifikasi kemungkinan terjadinya perbedaan pencatatan yang dapat berdampak pada menurunnya validasi dan akurasi data. Proses rekonsiliasi menjadi lebih efektif dan efisien dengan adanya aplikasi berbasis web $e$-Rekon-LK karena satker dapat mengerjakan rekonsiliasi dari kantor masing-masing sehingga mengurangi biaya perjalanan ke KPPN untuk melakukan rekonsiliasi, kemudian perbedaan sebagian data antara Sistem Akuntansi Instansi Berbasis Akrual (SAIBA) satuan kerja sampai dengan Kementerian/Lembaga dapat diselesaikan/dikurangi dengan aplikasi $e$-Rekon-LK, monitoring dapat dilakukan dengan lebih cepat karena aplikasi $e$-Rekon-LK memberikan informasi awal atas perekaman yang tidak normal seperti atas transaksi tidak normal dilakukan penelaahan dan koreksi bila diperlukan, monitoring data satker dapat dilakukan setiap hari baik monitoring laporan keuangan maupun monitoring atas pelaksanaan dan hasil rekonsiliasi, $e$ Rekon-LK juga memudahkan pengawasan dalam proses rekonsiliasi dan hasilnya.

Namun berdasarkan hasil yang didapat Peneliti, dalam implementasinya masih ditemukan hambatan atau tantangan yaitu (1) Adanya pergantian operator pada satuan Kerja akantetapi operator Satuan Kerja yang lama tidak mengajarkan mengenai program dan cara kerja (sharing knowledge) kepada operator yang baru hal tersebut berpengaruh terhadap pemahaman aplikasi e-Rekon-LK; (2) Belum adanya jaringan internet di daerah-daerah tertentu misalnya didaerah kepulauan hal tersebut berpengaruh pada saat mengupload data dari daerah tersebut hal tersebut mengakibatkan operator Satuan Kerja harus datang langsung ke KPPN atau mencari tempat yang ada jangkauan internetnya untuk mengupload data menggunakan username sendiri; dan (3) Data yang masuk kedalam single database SPAN bisa diakses banyak pihak/user, data harus diyakinkan pada level ini bahwa data SAI dan SiAP sama, valid, dan akurat. Namun berdasarkan informasi yang didapatkan penulis karena berbagai keterbatasan seperti kurangnya Sumber Daya Manusia Satuan Kerja yang bisa menjalankan komputer sekaligus internet, operator kurang teliti dalam penginputan data dan pihak Satuan Kerja yang tidak langsung memberitahukan ketika terjadi ralat Surat Perintah Membayar (SPM) menyebabkan data Sistem Akuntanis Instansi dan data Sistem Akuntansi Pemerintah tidak sama. 
Ditinjau dari alat analisis COSO (The Committee Of Sponsoring Organizations Of Treadway Commission), hasil analisa Peneliti untuk proses rekonsiliasi menggunakan aplikasi $e$-Rekon-LK yaitu:

1. $\quad$ Lingkungan Pengendalian(Control Invironment)

Lingkungan pengendalian dalam pelaksanaan rekonsiliasi menggunakan aplikasi $e$ -

Rekon-LK pada Kanwil DJPBN Provinsi Sulawesi Utara sudah memadai, dibuktikan dengan adanya aturan yang mengatur yaitu Peraturan Menteri Keuangan Republik Indonesia Nomor 104/PMK.05/2017 tentang Pedoman Rekonsiliasi Dalam Penyusunan Laporan Keuangan Lingkup Bendahara Umum Negara Dan Kementerian Negara/Lembaga, adanya struktur organisasi yang terdiri dari Kepala Bidang Pembinaan Akuntansi dan Pelaporan Keuangan, Kepala Seksi Pembinaan Sistem Akuntansi Pemerintah Pusat dan Daerah, serta Kepala Seksi Analisa Statistik dan Penyusunan Laporan Keuangan, orang-orang yang terlibat dalam proses rekonsiliasi adalah orang-orang yang berkompeten di bidangnya karena diseleksi dari test CPNS Kemenkeu dan Sekolah Tinggi Akuntansi Negara.

2. Penilaian Risiko (Risk Assessment)

Aplikasi $e$-Rekon-LK merupakan sistem rekonsiliasi yang dapat mendeteksi dengan cepat bila terjadi resiko perbedaan data, resiko perbedaan data akan terlihat pada saat proses rekonsiliasi dilevel terendah yaitu antara satker dan KPPN sehingga kesalahan tersebut dapat cepat diperbaiki, hal tersebut membuktikan kalau penilaian risiko dalam proses menggunakan aplikasi $e$-Rekon-LK di Kanwil DJPBN Provinsi Sulut sudah baik.

3. Aktivitas Pengendalian (Control Activities)

Aktivitas pengendalian dalam proses rekonsiliasi di Kanwil DJPBN Provinsi Sulut sudah memadai, dibuktikan dengan adanya otorisasi, verifikasi seperti diterbitkannya Berita Acara Rekonsiliasi yang telah di tandatangani secara elektronik oleh Kuasa Bendahara Umum Negara dan Kuasa Pengguna Anggaran untuk satker yang telah melaksanakan rekonsiliasi.

4. Informasi Dan Komunikasi (Information And Communication)

Proses rekonsiliasi menggunakan aplikasi $e$-Rekon-LK di Kanwil DJPBN Provinsi Sulut sudah memadai di buktikan dengan prosesnya yang sekaligus mengumpulkan, menganalisa, mengklasifikasi, serta memberikan informasi rekonsiliasi yang ada dengan cepat sehingga terlihat jelas oleh seluruh pengguna $e$-Rekon-LK dan mempercepat proses konsolidasi laporan keuangan Kementerian/Lembaga.

5. Aktivitas Pemantauan(Monitoring Activities)

Menurut informasi yang didapatkan peneliti dari wawancara dengan Bapak Eko Suharyanto selaku Kepala Seksi Analisa Statistik dan Penyusunan Laporan Keuangan, pihak Kanwil DJPBN Provinsi Sulut selalu melakukan evaluasi dalam rangka penyempurnaan infrastruktur sistem database aplikasi $e$-Rekon-LK. Hal tersebut membuktikan aktivitas pemantauan rekonsiliasi sudah baik.

\section{KESIMPULAN DAN SARAN}

\subsection{Kesimpulan}

Berdasarkan hasil penelitian dan pembahasan yang dilakukan dalam menganalisis aplikasi $e$-Rekon-LK terhadap rekonsiliasi laporan keuangan pada Kantor Wilayah Direktorat Jenderal Perbendaharaan Negara Provinsi Sulawesi Utara, maka dapat diambil kesimpulan sebagai berikut:

1. Aplikasi e-Rekon-LK memberikan terobosan dalam rekonsiliasi dan konsolidasi laporan keuangan tingkat Kementerian/Lembaga. Rekonsiliasi dapat dilakukan dari kantor satker. Integritas data juga menjadi lebih baik karena perbedaan data antara 
unit akuntansi satker dan unit akuntansi diatasnya tidak ada lagi atau perbedaan data antara satker dan Kantor Pelayanan Perbendaharaan Negara (KPPN) dapat diselesaikan lebih cepat. Proses konsolidasi laporan keuangan Kementerian/Lembaga juga menjadi lebih cepat. Proses monitoring dan pelaksanaan rekonsiliasi menjadi lebih baik karena aplikasi e-Rekon-LK memberikan informasi transaksi tidak normal untuk ditelaah. Monitoring juga cepat, dapat dilakukan tiap hari, karena data satker terkumpul dalam satu database yang dapat diakses oleh seluruh tingkatan unit akuntansi pada Kementerian/Lembaga.

2. Jika ditinjau menggunakan alat analisis $\mathrm{COSO}$, proses rekonsiliasi menggunakan aplikasi $e$-Rekon-LK sudah memadai dinilai dari lingkungan pengendalian, pengendalian resiko, aktivitas pengendalian, informasi dan komunikasi, dan aktivitas pemantauan.

3. Hambatan atau tantangan dalam proses rekosiliasi diantaranya: (1) Operator Satuan Kerja yang kurang paham akan program dan cara menggunakan aplikasi e-Rekon-LK; (2) Kurang bagusnya jaringan internet di daerah-daerah tertentu misalnya di kepulauan; (3) Operator kurang teliti dalam penginputan data.

\subsection{Saran}

Berdasarkan hasil penelitian dan pembahasan yang dilakukan dalam menganalisis aplikasi e-Rekon-LK terhadap rekonsiliasi laporan keuangan pada Kantor Wilayah Direktorat Jenderal Perbendaharaan Negara Provinsi Sulawesi Utara, maka penulis mengharapkan:

1. Kantor Wilayah Direktorat Jenderal Perbendaharaan Negara harus selalu memberikan edukasi kepada satuan kerja mitra kerjanya dalam meningkatkan Sumber Daya Manusia Satuan Kerja melalui bimtek, sosialisasi, dan workshop.

2. Menghimbau kepada satuan kerja yang memiliki masalah jaringan internet sebaiknya datang langsung ke Kanwil Direktorat Jenderal Perbendaharaan Negara (DJPBN), Kantor Pelayanan Perbendaharaan Negara (KPPN) atau mencari tempat yang memiliki jaringan internet yang bagus.

\section{DAFTAR PUSTAKA}

COSO. 2013. Internal Control - Integrated Framework : Executive Summary. North Carolina.

Langelo, F ., Saerang, D. P. E., Alexander, S. W., 2015. Analisis Penerapan Standart Akuntansi Pemerintahan Berbasis Akrual Dalam Penyajian Laporan Keuangan Pada Pemerintah Kota Bitung. Volume 3. Nomor 1. Jurnal EMBA. FEB UNSRAT: Manado.

Lord, S. 2013. An Overview of COSO's 2013 Control Intergrated Framework. https://rsmus.com/pdf/2013_coso_framework_update.pdf 3 Mei 2018 (20:35)

Peraturan Direktur Jenderal Perbendaharaan Nomor 36/PB/2009 tentang Pedoman Rekonsiliasi dan Penyusunan Laporan Keuangan Kuasa Bendahara Umum Negara. Jakarta

Peraturan Menteri Keuangan 010 Nomor 05 Tahun 2016 tentang Perubahan Atas Peraturan Menteri Keuangan. Jakarta.

Peraturan Menteri Keuangan 05 Nomor 213 Tahun 2013 Sistem Akuntansi dan Pelaporan Keuangan Pemerintah Pusat. 31 Desember 2013. Menteri Keuangan Republik Indonesia. Jakarta.

Peraturan Menteri Keuangan Nomor 233/PMK.05/2011 tentang Perubahan Atas Peraturan Menteri Keuangan Nomor 171/PMK.05/2007 tentang Sistem Akuntansi dan Pelaporan Keuangan Pemerintah Pusat. Jakarta

Peraturan Pemerintah Republik Indonesia Nomor 71 Tahun 2010 tentang Standar Akuntansi Pemerintahan. Lembaran Negara Republik Indonesia Tahun 2010 Nomor 47. Jakarta. 
Sujarweni, V. W. 2015. Akuntansi Sektor Publik. Edisi Pertama. Cetakan Pertama. Penerbit Pustaka Baru Press. Yogyakarta.

Syahdan, S. A. 2012. Analisis Proses Rekonsiliasi Pada Kantor Pelayanan Perbendaharaan Negara (KPPN) Banjarmasin. Skripsi. Sekolah Tinggi Ilmu Ekonomi Indonesia. Banjarmasin.

Undang-Undang Nomor 1 Tahun 2004. Perbendaharaan Negara. 14 Januari 2004. Lembar Negara Republik Indonesia Tahun 2004. Jakarta 